\title{
Wdrożenie aplikacji internetowych wspomagających zarządzanie przedsiębiorstwem na przykładzie wybranej gminy
}

\author{
Mateusz Poniatowski*, Elżbieta Miłosz \\ Politechnika Lubelska, Instytut Informatyki, Nadbystrzycka 36B, 20-618 Lublin, Polska
}

\begin{abstract}
Streszczenie. W artykule opisano wdrażanie aplikacji internetowych wspomagających zarządzanie przedsiębiorstwem, w oparciu o wdrożenia w poszczególnych biurach podróży. Przedstawiono różne typy aplikacji internetowych z analizą zalet i wad ich użycia. W analizie zastosowano metodę sondażu diagnostycznego. Wyniki badań wykazały, że najpopularniejszą aplikacją stosowaną przez biura podróży jest CRM. Przedsiębiorstwa wykazały, że aplikacje były wdrożone bez opóźnień, a główną korzyścią ich posiadania jest wzrost sprzedaży.
\end{abstract}

Słowa kluczowe: wdrożenie; zarządzanie; aplikacje internetowe

*Autor do korespondencji.

Adres e-mail: mateusz.poniatowski@pollub.edu.pl

\section{Implementation of web applications supporting business management basing on companies in chosen geographic area}

\author{
Mateusz Poniatowski*, Elżbieta Miłosz \\ Institute of Computer Science, Lublin University of Technology, Nadbystrzycka 36B, 20-618 Lublin, Poland
}

\begin{abstract}
The article describes implementation of internet applications supporting business management, basing on implementations in particular travel agencies. Various web application types of were presented, with the analysis of pros and cons of their usage. Diagnostic survey method was used in the analysis. Results of research have shown, that most popular web application used by travel agencies is CRM. Companies from travel business line proved efficiency of this tool, by increase of sales performance.
\end{abstract}

Keywords: implementation; management; web applications

*Corresponding author.

E-mail address: mateusz.poniatowski@ pollub.edu.pl

\section{Wstęp}

Ważnym aspektem pracy każdego przedsiębiorstwa jest proces jego zarządzania oraz odpowiednie wykorzystywanie technologii informatycznych takich jak aplikacje internetowe. Wyzwaniem dla każdej firmy jest nadanie jej indywidualnego charakteru. Może w tym pomóc stworzenie dedykowanej aplikacji internetowej. Warto więc zbadać proces wdrożenia tych aplikacji, dowiedzieć się jakie technologie są najbardziej popularne, jakie mają obawy przedsiębiorstwa związane z wdrożeniem aplikacji internetowych oraz jakie odnoszą korzyści.

\section{Aplikacje internetowe w zarządzaniu przedsiębiorstwem}

Do zarządzania współczesnym przedsiębiorstwem wymagane jest wykorzystywanie odpowiednich rozwiązań IT. W ostatnich latach znacząco zwiększyła się rola systemów informatycznych w przedsiębiorstwach. Automatyzacja, optymalizacja procesów, wspomaganie w podejmowaniu decyzji oraz poprawa relacji z klientami to główne czynniki wpływające na wzrost popularności wszelakich rozwiązań IT w biznesie. Aplikacja internetowa, często nazywana aplikacją webową, to program komputerowy, który do realizacji funkcjonalności wymaga koniecznie dostępu do sieci Internet [6]. Interfejs takiej aplikacji dostępny jest za pomocą przeglądarki internetowej. Ponadto to także rozwiązania, które:

- wykorzystują języki programowania wspierane przez przeglądarki np.: HTML, JavaScript,

- posiadają architekturę klient-serwer,

- komunikują się za pomocą protokołu $\operatorname{HTTP}(\mathrm{S})$.

Działanie aplikacji internetowej wymaga serwera WWW, także serwera aplikacji w celu wykonywania żądań oraz bazy danych do przechowywania informacji. Działanie aplikacji internetowej można opisać według następujących etapów:

1) Uruchomienie żądania do serwera internetowego przez użytkownika za pośrednictwem przeglądarki internetowej.

2) Serwer WWW przekazuje żądanie do konkretnego serwera aplikacji.

3) Serwer aplikacji wykonuje żądanie np. zapytanie do bazy danych.

4) Serwer sieciowy odpowiada już klientowi, któremu w przeglądarce ukazują się żądane informacje.

Aplikacje internetowe pomagają przedsiębiorstwom zająć na rynku odpowiednią pozycję, co sprawia, że cały czas 
najczęściej wykorzystywane są do prowadzenia działalności systemy ERP i CRM. Dzieje się tak, ponieważ służą one do optymalizowania i zarządzania procesami zachodzącymi w przedsiębiorstwie. Zarówno pierwszy jak i drugi system rozpowszechnia informacje w całym przedsiębiorstwie, jednak ERP bardziej jest skupiony na wszystkich procesach przedsiębiorstwa, a CRM tylko na procesach związanych $\mathrm{z}$ relacjami z klientami [6].

Wiele dostępnych źródeł [1,2,3] podaje, że system ERP jest to narzędzie informatyczne, które usprawnia zarządzanie przedsiębiorstwem, gdyż obejmuje wszystkie działy danej firmy. To sprawia, że system taki pozawala bardziej efektywnie zarządzać przedsiębiorstwem, gdyż w każdej chwili możliwy jest podgląd do niezbędnych informacji, które można na bieżąco w szybki sposób analizować. Ułatwia to planowanie przyszłych działań, gdyż bieżące są w pełni kontrolowane. Wśród zalet można wymienić jeszcze przyspieszoną obsługę klienta oraz skrócenie czasu oczekiwania na realizację np. danego zamówienia, czy wykonania obsługi serwisowej.

Natomiast system CRM to system do zarządzania relacjami z klientami poprzez zespół różnych czynności, działań, elementów potrzebnych do zarządzania tymi relacjami. Kluczem do sukcesu prawidłowego funkcjonowania firmy jest posiadanie odpowiednio zasobnej grupy klientów, którzy generują zyski. Ten argument sprawia, że klienci zasługują na udogodnienia $\mathrm{w}$ postaci funkcjonalnych systemów IT. Do stworzenia podstawowej bazy informacji o klientach i nadania jednolitego obrazu firmy wykorzystuje się różne strategie CRM.

\section{Wybrane problemy wdrożeń systemów informatycznych}

W dzisiejszych czasach wdrożenie systemów IT nie jest takie proste jak było to jeszcze niedawno. Powstają coraz to nowe narzędzia technologiczne, a metodyki i sam proces wdrażania również się zmieniają.

Wdrożenie aplikacji internetowych to proces, który żeby zrozumieć należałoby poznać wszystkie etapy związane z projektem informatycznym (od czasu powstania pomysłu na daną aplikację do momentu udostępnienia oraz jej eksploatacji przez użytkowników). Jednak przede wszystkim wdrożenie systemu wiąże się $\mathrm{z}$ wyborem pewnej metodyki takiego wdrożenia już na etapie tworzenia oprogramowania. Przy wdrażaniu systemów informatycznych (bez względu na wybraną metodykę) na etapie planowania nie można zapomnieć o dokumentacji i spisaniu wymagań funkcjonalnych, niefunkcjonalnych oraz diagramach np. UML [5]. Najbardziej popularne typy modeli to: kaskadowe, spiralne, przyrostowe, RUP i zwinne. Wadą podejścia kaskadowego jest to, że nie można przejść do kolejnych etapów bez zakończenia poprzednich, czyli brak elastyczności. Ponadto metodyka ta jest prawie niemożliwa w dzisiejszych czasach do zastosowania, ze względu na złożoność projektów oraz brak precyzyjnie sformułowanych wymagań ze strony klienta. Dodatkowo programiści nie są w stanie przewidzieć problemów technicznych związanych $\mathrm{z}$ implementacją projektu, co może wpłynąć na wydłużenie czasu oddania projektu. Metodyka ta potrafi generować ogromne koszty dla przedsiębiorców. Zaletą wykorzystania tego podejścia jest stworzenie bardzo czytelnej, dokładnej dokumentacji.

Drugi omawiany model to model spiralny, który został zdefiniowany przez Barry'ego Boehm'a. Cały proces przypomina spiralę, ze względu, że każda kolejna pętla ukazuje następne fazy procesu wdrażania. Ten model metodyki daje korzyści związane $\mathrm{z}$ dużą niezawodnością, a także szansą, że projekt będzie zrealizowany. Sposób ten jest odpowiedni dla dużych projektów informatycznych. Wadą tego podejścia jest to, że wymaga bardzo doświadczonych ekspertów w dziedzinie analizy ryzyka zarówno w dziedzinie IT jak i w biznesie. Kolejny omawiany model to model przyrostowy. Najważniejszą cechą tego modelu jest to, że funkcjonalności aplikacji są dzielone na porcje. W iteracjach te porcje funkcjonalności są dostarczane w różnych dziedzinach (np. wymagania, implementacja) [5].

Najczęściej wykorzystywaną metodyką zwinną jest Scrum, a wdrożenie aplikacji internetowej przy wykorzystywaniu tej metodyki składałoby się z:

- etapu przygotowań,

- etapu wdrożenia.

Etap przygotowań to proces, na który składa się głównie analiza potrzeb klienta przez dostawcę. Gdy już są określone potrzeby, wykonawca wycenia funkcjonalności, a klient ustala listę priorytetów. Dodatkowo na tym etapie powinien być ustalony budżet projektu oraz właściciel produktu. Następnym etapem jest wdrożenie. W Scrumie, wdrożenie jest podzielone na kolejne etapy, czyli Sprinty, które mogą trwać od jednego do nawet kilku tygodni. Najważniejszą zasadą jest, aby Sprint zawsze był o stałej długości. Sprint złożony jest $\mathrm{z}$ etapu planowania, w którym programiści dostają od właściciela produktu listę wymagań, jakie mają zostać zrealizowane. Kolejnym etapem jest praca programistyczna, w której programiści implementują spisane wcześniej wymagania. W tym etapie osoba lub osoby reprezentujące przedsiębiorstwo nie mogą zmieniać celów planowanego przyrostu. Ostatnie dwa etapy to:

- etap oddania, w którym wykonawca pokazuje klientowi efekt swojej pracy,

- etap podsumowania, w którym zarówno klient jak i dostawca aplikacji podsumowują ostatni Sprint.

Po tych etapach następuje kolejne planowanie i praca nad kolejnym Sprintem [7].

Podczas wdrażania sytemu klasy ERP czy CRM do uzyskania zakładanej potrzeba czasu, sięgającego nawet kilku miesięcy. Oczywiście wiążą się z tym także koszty, ale przy właściwym wdrożeniu systemu opłacalność będzie większa niż poniesione straty czasowe i finansowe. Przed rozpoczęciem dokonania takich zmian w firmie, należy przeprowadzić wstępną analizę i zadać sobie kilka pytań. Przede wszystkim, czy przedsiębiorstwo dysponuje odpowiednim budżetem, jaki stopień wykwalifikowania posiadają pracownicy, ponieważ konsultacja ze specjalistą i nawiązanie z nim współpracy generuje kolejne wydatki. Do 
wdrożenia systemu CRM potrzebna jest wiedza i wysiłek. Ustalenie polityki stosowanej z partnerami czy dostawcami będzie ważyło o dalszym postępowaniu. Trzeba również zmienić podejście do klienta, który ma stać w centrum i to jego potrzeby będą priorytetami w działaniu i funkcjonowaniu biznesu. Wdrażanie nowego systemu wiąże się $\mathrm{z}$ systematycznością i koniecznością przestrzegania zaplanowanych terminów i zadań. Istnieje niebezpieczeństwo, że sukces nie zostanie odniesiony wbrew założeniom, zwłaszcza w przypadku podejmowaniu niekorzystnych działań. Nie można podejmować decyzji o wprowadzeniu zmian bez wcześniejszego przemyślenia i kalkulacji. Potrzebne jest odpowiednie przygotowanie odpowiednich procesów, aby wdrożenie systemu informatycznego nie okazało się bezwartościowe. Kolejnym błędem może być wykorzystanie gotowego pakietu, a skutkiem takiego wyboru może stać się brak połączenia $\mathrm{z}$ bazą danych lub przymusowe wprowadzanie informacji. To natomiast wiąże się z wydłużeniem czasu. Należy pamiętać, że każde zmiany i działania wprowadzane $w$ trakcie ulepszania nowego systemu w firmie powinny być spisywane, a wszelkie dokumenty przechowywane [7].

Decydując się na wdrożenie systemu informatycznego należy przekalkulować opłacalność i efektywność. Wyrażenie efektywności systemu informatycznego można przedstawić za pomocą zależności między całkowitymi nakładami, takimi jak: koszty systemu, koszty adaptacji i eksploatacji koszty sprzętu IT, koszty szkoleń, koszty czasu pracy pracowników biorących udział we wdrożeniu systemów informatycznych a efektami, jakie wynikają $\mathrm{z}$ wdrożenia oraz eksploatacji (korzyści materialne i niematerialne).

Ogólna ścieżka etapów wdrożenia systemu może być przedstawiona w następującej kolejności [3]:

- założenie zespołu projektowo-analitycznego,

- analiza potrzeb,

- określenie funkcjonalności systemu,

- wybór rozwiązania,

- przeprowadzenie wdrożenia systemu.

Trzeba pamiętać, że nie ma jednolitego schematu, ani metody uniwersalnej, która każdej firmie zapewni sukces. Trzeba także być przygotowanym, że wdrożenie może trwać nawet kilkanaście miesięcy i tego czasu niestety nie da się skrócić. Jednym $\mathrm{z}$ warunków, żeby uznać, że wdrożenie odbyło się prawidłowo jest sprawdzenie dokumentacji, w skład której powinna wchodzić dokumentacja dla użytkowników oraz dla administratora. Efektami wdrożenia systemów IT są:

- wzrost wydajności pracy,

- zwiększone bezpieczeństwo danych w przedsiębiorstwie,

- lepszy, szybszy dostęp do danych biznesowych,

- poprawa kontaktu z klientem,

- przyspieszenie procesów np. decyzyjnych, biznesowych, sprzedażowych [7].

\section{Założenia i przebieg badań}

Większość przedsiębiorstw działających na terenie gminy Lublin ma dostęp do aplikacji internetowych. Są to aplikacje różnego typu, dlatego też celem badań było zbadanie procesu wdrożenia, a co się $\mathrm{z}$ tym wiąże, także oczekiwanych korzyści, spodziewanych obaw oraz zweryfikowanie, który rodzaj aplikacji internetowych jest najczęściej wykorzystywany wśród biur podroży prowadzących działalność na terenie gminy Lublin. Dla realizacji celu postawiono następujące pytania badawcze:

1. Jaki typ aplikacji internetowych jest najczęściej wykorzystywany przez przedsiębiorstwa?

2. Jaki język programowania jest najczęściej wykorzystywany do implementacji aplikacji internetowych?

3. Jaka była główna obawa przedsiębiorstw, związana z wdrożeniem aplikacji internetowej w okresie planowania wdrożenia?

4. Jaka jest główna zaleta wdrożenia aplikacji internetowej wspomagającej zarządzanie przedsiębiorstwem?

5. Jaki był najczęstszy problem przedsiębiorstw, związany z aplikacją internetową wspomagającą zarządzanie po wdrożeniu?

6. Czy w przedsiębiorstwach, które wdrożyły aplikacje internetowe czas wdrożenia na etapie planowania był odpowiednio oszacowany?

Postawione pytania badawcze pozwoliły sformułować następujące hipotezy badawcze:

H1: Zdecydowana większość przedsiębiorstw wykorzystuje aplikacje internetowe, które opierają się na systemie CRM.

H2: Najbardziej popularny język programowania wykorzystywany do implementacji aplikacji internetowych wspomagających zarządzanie przedsiębiorstwem to PHP.

H3: Główną obawą przedsiębiorstw w okresie planowania wdrożenia aplikacji internetowej jest kwestia związana $\mathrm{z}$ bezpieczeństwem danych.

H4: Największą korzyścią wdrożenia aplikacji jest przyspieszenie procesów biznesowych.

H5: Głównym problemem przedsiębiorstw związanym z wdrożeniem aplikacji internetowej jest wolne działanie aplikacji uzależnione od parametrów posiadanego łącza internetowego.

H6: Czas wdrożenia aplikacji internetowych okazał się być dłuższy niż planowano.

Realizacja badań odbyła się metodą sondażu diagnostycznego z wykorzystaniem ankiety internetowej, a więc techniką CAWI (Computer-assisted Web Interview).

Próbę badawczą stanowiły biura turystyczne w mieście Lublin. Ankieta była przeprowadzona na przełomie listopada i grudnia 2018 roku. Adres, pod którym była ona dostępna został przesłany drogą elektroniczną na adresy e-mail 15 biur turystycznych zarejestrowanych na terenie gminy Lublin. Jednak ze względu na małe zainteresowanie, badania odbyły się przy obecności ankietera w siedzibach biur turystycznych. Końcowo ankietę wypełniło 30 pracowników z przedsiębiorstw takich jak: Koliber,Continental-Travel, Astur, Gala-Travel, Sass, Coral-Tour, Happy Tour.

\section{Wyniki badań $i$ ich analiza}

Zebrane dane uzyskano od pracowników biur turystycznych. Poprzez analizę zebranych danych, można 
stwierdzić, że biura turystyczne w gminie Lublin zdają sobie sprawę, że w dzisiejszych czasach aplikacja internetowa jest niezbędna do zdobycia i podtrzymywania pozycji na rynku. Świadczą o tym wyniki ankiety, w których $100 \%$ badanych przedsiębiorstw wykazuje, że posiada różnego rodzaju aplikacje internetowe.

W zdecydowanej większości, bo aż w $67 \%$ badanych biur turystycznych, dominuje system CRM jako aplikacja internetowa wspomagająca zarządzanie. Dużą popularnością cieszą się również aplikacje ogłoszeniowe - $23 \%$ respondentów korzysta z tego typu aplikacji (Rys.1).

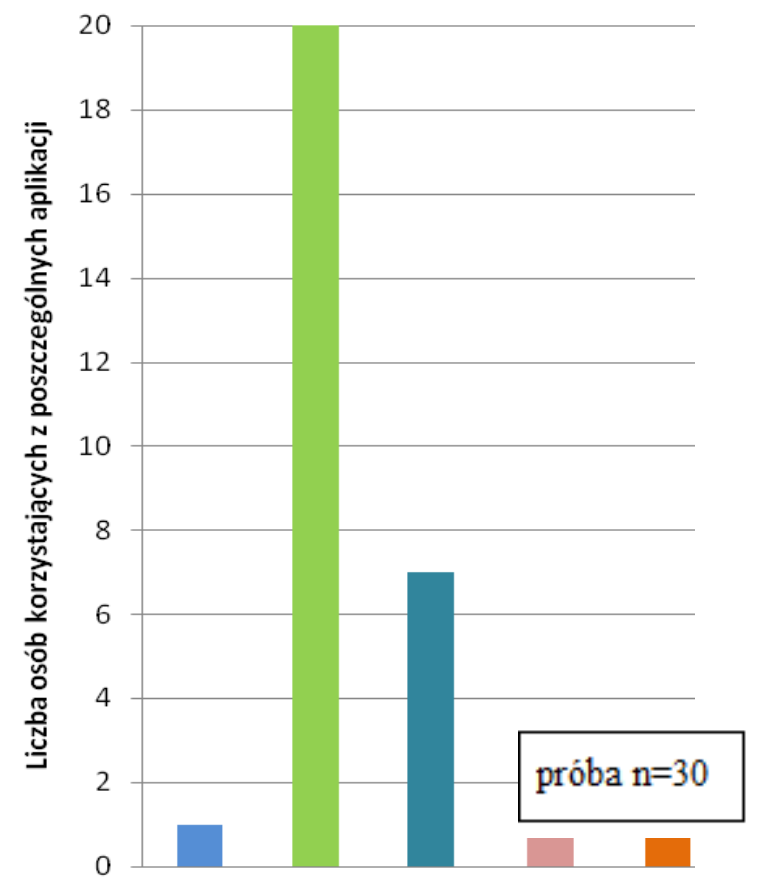

- System ERP

- System CRM

Aplikacja ogłoszeniowa

- Aplikacja bookingowa

\section{próba $\mathrm{n}=30$}

Aplikacja sprzedażowa

Rys. 1. Rodzaj aplikacji wdrożonych w przedsiębiorstwach

W przedstawionym poniżej wykresie (Rys.2), ukazane zostały odpowiedzi respondentów, w których wskazują oni po trzy główne korzyści wdrożenia aplikacji internetowych. Najczęstsze odpowiedzi to:

- jest to wzrost sprzedaży,

- zwiększenie konkurencyjności firmy,

- lepszy kontakt z klientem,

- większa możliwość rozwoju firmy.

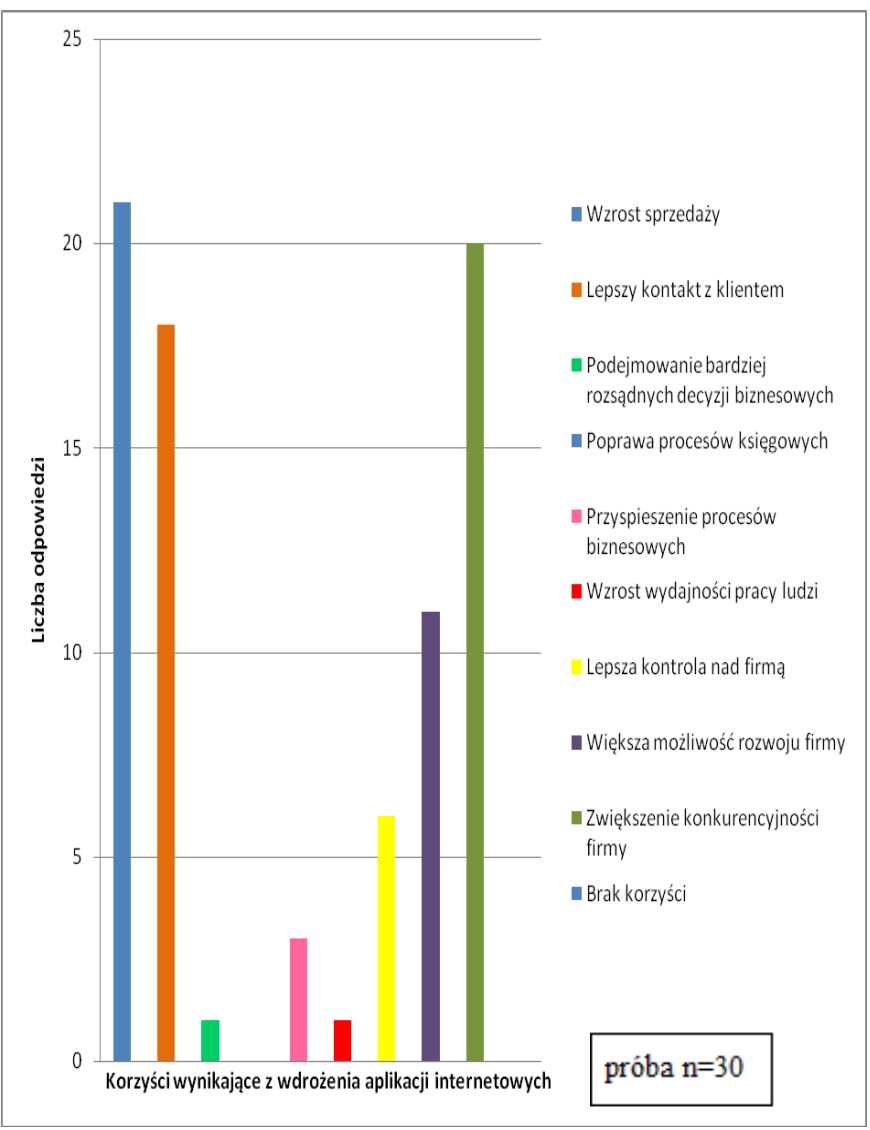

Rys. 2. Korzyści wynikające z wdrożenia aplikacji internetowych

Kolejne pytanie dotyczyło obaw związanych z wdrożeniem aplikacji internetowych, które pojawiały się na etapie planowania. Przy tym pytaniu respondenci podzielili się na dwie grupy badanych. Pierwsza to grupa, która miała obawy, druga to ta, która nie odczuwała żadnych obaw w związku z wdrożeniem. 37\% ankietowanych wskazało, że najbardziej obawiają się awarii aplikacji. Drugą najczęściej wskazywaną obawą był brak doświadczenia pracowników. Natomiast $50 \%$ wszystkich respondentów wcale nie miało obaw związanych z wdrożeniem aplikacji internetowej (Rys.3).

Kolejne pytanie ankiety miało za zadanie zbadać, jaki jest najczęstszy problem korzystania $\mathrm{z}$ aplikacji internetowych już po etapie wdrożenia. $74 \%$ respondentów wskazało, że głównym problemem jest wolne działanie aplikacji. Kolejnym problemem okazuje się być również niewystarczający zakres szkolenia $\mathrm{z}$ obsługi działania aplikacji dla pracowników (Rys.4.).

Ostatnie pytanie dotyczyło weryfikacji oszacowanego czasu wdrożenia aplikacji z etapu planowania. $63 \%$ badanych wykazało, że czas wdrożenia był odpowiedni, zgodny z tym czasem, który zaplanowano. Tylko $17 \%$ ankietowanych odpowiedziało, że system wdrożono z opóźnieniem. 


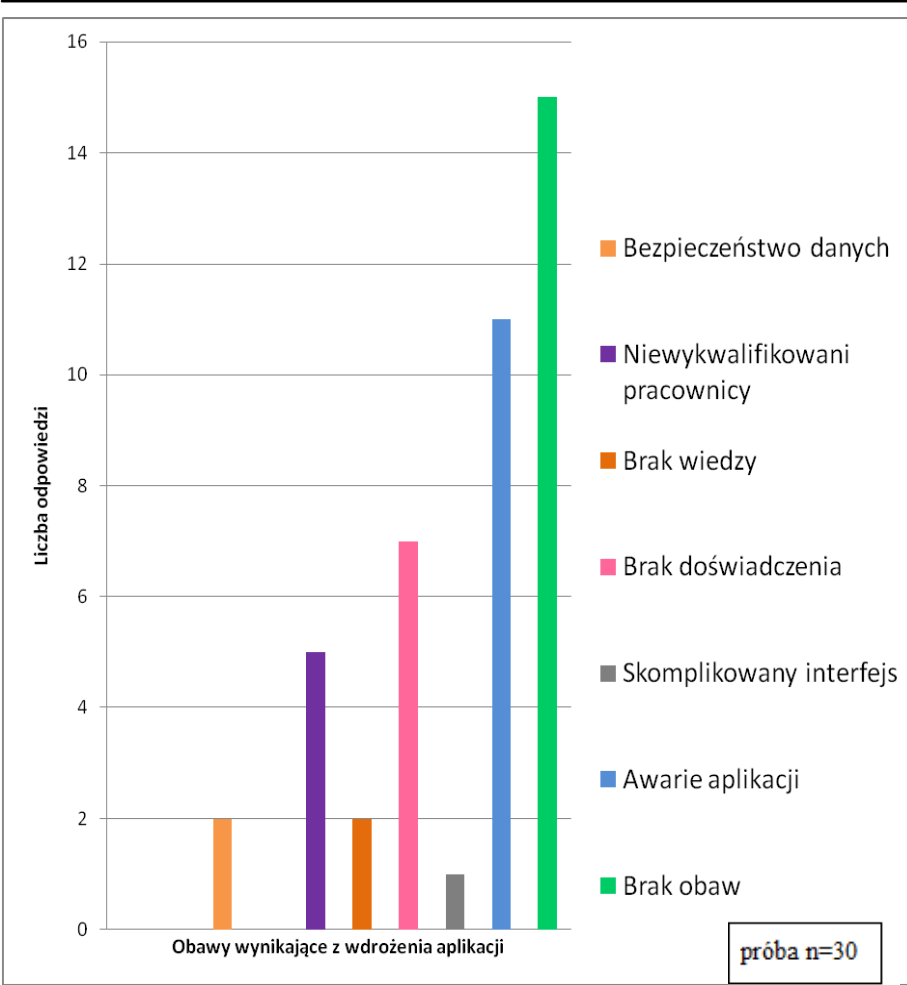

Rys. 3. Obawy wynikające $\mathrm{z}$ wdrożenia aplikacji

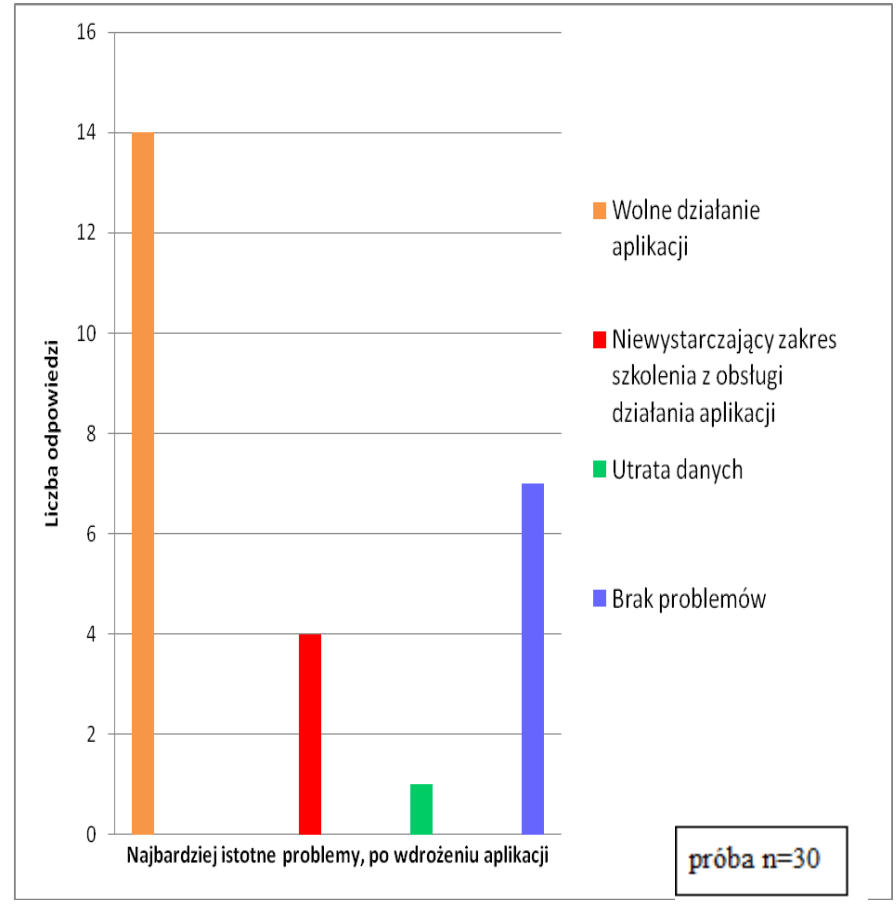

Rys. 4. Najbardziej istotne problemy, po wdrożeniu aplikacji

\section{Wnioski}

Analiza badań wykazała, że wszystkie biura turystyczne mają świadomość konieczności posiadania aplikacji internetowej. Każde badane przedsiębiorstwo posiada aplikację internetową, z której aktywnie korzysta. W pracy zostało postawionych sześć hipotez, z czego trzy zostały potwierdzone.
Pierwsza hipotezy, która zakładała, że w większości przedsiębiorstw związanych $\mathrm{z}$ turystką zarejestrowanych na terenie gminy Lublin wykorzystuje się aplikacje internetowe, głównie w postaci systemów CRM, została potwierdzona.

Druga hipoteza, która zakładała, że najbardziej wykorzystywanym językiem programowania służącym do implementacji aplikacji internetowych wspomagających zarządzanie przedsiębiorstwem na przykładzie biur podróży jest PHP, została potwierdzona.

Trzecia hipoteza, która zakładała, że główną obawą przedsiębiorstw $\mathrm{w}$ okresie planowania wdrożenia aplikacji internetowej była kwestia związana $\mathrm{z}$ bezpieczeństwem danych, została obalona. $\mathrm{Z}$ odpowiedzi ankietowanych wynika, że ponad $50 \%$ respondentów nie miało wcale obaw związanych z wdrożeniem aplikacji. Natomiast 37\% ankietowanych wykazało, że największą obawą są ewentualne awarie aplikacji.

Czwarta hipoteza, która zakładała, że największą korzyścią wdrożenia aplikacji jest przyspieszenie procesów biznesowych, została obalona. 70\% respondentów wykazało, że największą korzyścią aplikacji internetowej jest wzrost sprzedaży.

Piąta hipoteza, która zakładała, że głównym problemem przedsiębiorstw związanym $\mathrm{z}$ aplikacją internetową są utrudnienia związane z prawidłowym działaniem aplikacji ze względu na prędkość posiadanego łącza internetowego, została potwierdzona. $74 \%$ respondentów wykazało, że po wdrożeniu aplikacji to był najczęściej występujący problem.

Szósta hipoteza, która zakładała, że czas wdrożenia aplikacji internetowych okazał się być dłuższy niż planowano, została obalona. $63 \%$ respondentów wykazało, że czas wdrożenia był odpowiednio oszacowany na etapie planowania.

\section{Literatura}

[1] Adamczewski P., Zintegrowane systemy informatyczne w praktyce, Warszawa 2003.

[2] Beynon-Davies, P. Inżynieria systemów informacyjnych. Warszawa: WNT, 1999.

[3] Chmielarz W. 1996. Systemy informatyczne wspomagające zarządzanie. Aspekt modelowy w budowie systemów. Warszawa: Wyd. Dom Wydawniczy Elipsa: 36.

[4] Dziembek D.: Rozwiązania Cloud Computing we wspomaganiu strategii kodyfikacji wiedzy w organizacji wirtualnej, Pr. Nauk. UE Wroc. nr 212, Inform. Ekon. nr 22, Wrocław 2011.

[5] Grudzewski W., Metody projektowania systemów zarządzania. Difin, Warszawa, 2004.

[6] Januszewski A., Funkcjonalność informatycznych systemów zarządzania, Warszawa 2008.

[7] Zalewski W., Analiza systemów informatycznych wspomagających zarządzanie produkcją w wybranych przedsiębiorstwach. Economy and Management - 4/2011. 